Open Access

\title{
Examination of sustainability reporting practices in Indian banking sector
}

\author{
Kishore Kumar $^{*}$ (iD and Ajai Prakash
}

\author{
* Correspondence: \\ akishore001@gmail.com \\ Department of Business \\ Administration, University of \\ Lucknow, Lucknow, Uttar Pradesh \\ 226007, India
}

\begin{abstract}
Sustainability reporting is at the core of designing corporate sustainability environment. The study has been conducted on Indian banking sector to examine the extent of sustainability reporting by the banks operating in India. Sustainability report, corporate social responsibility report, business responsibility report and annual report (FY 2015-16 \& 2016-17) of the banks were analysed and coded using content analysis technique against sustainability indicators derived from review of literature, GRI G4 guidelines, and National Voluntary Guidelines on responsible business conduct.

This is one of the first studies to examine the extent of sustainability reporting by the commercial banks in India in line with major sustainability-related standards \& guidelines. The result of the study shows that the banks in India are much slower in adopting sustainability reporting practices. It was found that sustainability issues which are of the highest priorities for the banks are directly related to their business operations like financial inclusion, financial literacy, energy efficient technology etc. The environmental consideration indicators are relatively unaddressed by most of the banks in India. The results of the study also show that there is a significant difference in the disclosure of environmental and internal socio-environmental indicators between public and private sector banks in India. This study is expected to contribute to banking sector and all the stakeholders in understanding more about the limitations in implementing sustainable reporting in India.
\end{abstract}

Keywords: Sustainability reporting, GRI, UNGC principles, Sustainable banking, NVGs, Corporate social responsibility

\section{Introduction}

Sustainability forms the core of corporate sustainability and is of utmost concern to all the stakeholders. There has been a growing awareness among the corporates to address environmental, social and governance (ESG) issues to contribute towards sustainable development. The development of sustainable organisations by improving environmental and social performance has become a global challenge for businesses around the world (Marrewijk 2003). There have been many studies addressing the need for incorporating sustainability into core business strategy (Dyllick and Hockerts 2002; Salzmann et al. 2005; Weber et al. 2008). Banking sector plays a crucial role in promoting sustainable development as it acts as an intermediary in the development of economy (Jeucken and Bouma 1999; Scholtens 2009). Prior literature shows that initially sustainable practices of the banks were confined to internal environmental management practices for energy efficiency, less resource consumption, and low carbon

(c) The Author(s). 2019 Open Access This article is distributed under the terms of the Creative Commons Attribution 4.0 International License (http://creativecommons.org/licenses/by/4.0/), which permits unrestricted use, distribution, and reproduction in any medium, provided you give appropriate credit to the original author(s) and the source, provide a link to the Creative Commons license, and indicate if changes were made. 
emission (Babiak and Trendafilova 2011), later complemented with the integration of environmental issues in lending and financing activities in the banking operations (Scholtens 2006; Johnsen 2003). The paradigm shift in the banks strategies to integrate environment, social and governance (ESG) issues in banking operations is crucial for moving towards sustainable development (van Gelder 2006). The banking sector is increasingly implementing sustainable banking practices as an important tool to address sustainable development issues (IFC 2007). The adoption of innovative sustainable products \& services by the banks has witnessed tremendous growth in the recent years (Krosinsky and Robins 2008). The emergence of nonfinancial reporting through BRR, SR, CSR report and the likes, in the past two decades has been an attempt by the organizations to engage all the stakeholders in information dissemination and communicate nonfinancial performance of the business on environmental \& social issues (Khan et al. 2009). Various frameworks, guidelines and standards have been evolved nationally and internationally like National Voluntary Guidelines (in India), Global Reporting Initiative (GRI), United Nation Global Compact (UNGC) principles, ISO 14001 and ISO 26000 which are widely adopted by organisations to improve social \& environmental performance (Isaksson \& Steimle 2009; Gupta \& Mohanty 2014; Mitra \& Schmidpeter 2017). Range of studies have been conducted in the field of sustainability reporting especially, in developed and developing economies (see, Willis 2003; Frost et al. 2005; Raman 2006; Roca \& Searcy 2012; Khan et al. 2009; Ghosh 2017), but there is scant empirical research on the extent of sustainability reporting by Indian companies. The content of nonfinancial reporting particularly in the Indian banking sector too is understudied. It is in this context, this study attempts to answer following questions. How the banks in India report their sustainable practices? Is there any variation in the sustainability reporting practices of PSBs and private sector banks in India?

This study identifies three broad dimensions of sustainability disclosure practices through review of literature on sustainability reporting trends and prominent sustainability reporting frameworks. It further examines the performance/compliance of the banks to each of the identified indicators. Next, this study examines whether sustainability reporting by public sector banks (PSBs) and private sector banks in India specifically consider the major indicators provided in sustainability-related disclosure guidelines such as GRI G4 guidelines, and NVGs.

The following paper is organised under five sections. The first part which is already discussed is the introduction followed by the second section which provides an overture of various prominent guidelines \& standards of sustainability disclosure and review of literature. The third section discusses recent initiatives taken by India to incorporate sustainable practices in businesses followed by a brief overview of banking sector in India. The fourth section provides the purpose of the study, research methodology, analysis and findings. Fifth and final section discusses the conclusion, research implications and limitations of the study.

The emergence of GRI guidelines, UNGC principles, NVGs, and their role in promoting corporate sustainability

In the past two decades, various standards frameworks and guidelines have been developed that helps the business organizations to understand and incorporate the critical 
sustainability issues into their corporate strategy. The GRI guidelines, UNGC principles, and NVGs are widely adopted by the business organisation to enhance the understanding and adoption of sustainability reporting practices (Weber et al. 2014). The driving spirit behind these guidelines and principles is to make business organisations more responsible and drive them towards sustainable development. The companies adopting these principles and guidelines need to disclose information about their economic, environmental and social performance.

\section{Global reporting initiatives (GRI)}

GRI was established in 1997 as a non-profit independent organisation in Boston USA, to enable the business organisations to assess and disclose economic, environmental and social performance. GRI is the most widely used standard for sustainability reporting by business organisations. It has been adopted by almost $93 \%$ of the world's largest 250 corporations across 100 countries (GRI 2018). It helps the companies to not only disclose nonfinancial performance but also encourages them to manage the impact of their activity on environment and reflect how they contribute towards sustainable development (Sethi 2017).

\section{United nation global compact principles}

The UN Global Compact's ten principles are derived from; The Rio Declaration on Environment and Development, Universal Declaration of Human Rights, The International Labour Organization's Declaration on Fundamental Principles and Rights at Work, and The United Nations Convention Against Corruption. It encourages the companies to adopt a principle-based approach to incorporate sustainability by embracing the core values of human rights, labour standards, environment, and anti-corruption.

\section{National Voluntary Guidelines (NVGs)}

It is the most progressive framework for responsible business conduct and corporate sustainability in India. These guidelines were the result of the need for standardised framework in Indian context similar to other internationally accepted sustainability reporting frameworks (Mitra \& Schmidpeter 2017). The basic rationale behind these guidelines is to provide a platform to companies in India to adopt and disclose their environmental and social performance through reporting of NVGs.

\section{Sustainability reporting}

The need for corporate sustainability and reporting of sustainable practices has acquired a pivotal importance in the past two decades. Disclosure of environmental and social performance has become an integral part of the company's overall business strategy (Ghosh 2017). Nonfinancial performance disclosure in the form of CSR reports, BRR and Sustainability reports are perceived as strong commitment of the organisations towards adoption of sustainable practices by various stakeholders (Raman 2006). The nonfinancial reporting by companies started with disclosure of socially responsible practices followed by environmental performance disclosure as a part of corporate social responsibility reporting (Jenkins \& Yakovleva 2006). The concept of nonfinancial 
reporting has been continuously evolving over the past three decades. Companies have now evolved the structure of non financial reporting from a miniscule couple or more sections in the annual report of the company to separate sustainability reporting. Such extensive reports involve complete disclosures of social and environmental performance of company's operations (KPMG 2017). Business organisations have become more responsible and have adopted international guidelines on sustainability reporting like GRI. This creates benchmarks and higher levels of transparency in the disclosure (Milne \& Gray 2007). According to KPMG (2015), more than 95\% of the 250 world's largest corporations publish sustainability reports. Various researches also suggest that organisations can benefit in many ways from CSR/sustainability reporting (Healy et al. 1999; Khan et al. 2009). There has been extensive research in developed and developing countries highlighting the nature and content of CSR disclosure of companies (like Gray et al. 1995; Willis 2003; Frost et al. 2005; Raman 2006; Roca \& Searcy 2012; Khan et al. 2009; Boiral \& Henri 2017; Ali et al. 2017).

Recently there is increased consciousness to adopt and report sustainability issues in financial institutions (Khan et al. 2009). Islam et al. (2016) noted that banks have exhibited conscious efforts to comply with environment related regulations and disclosure of environment management policy to incorporate environmental considerations in banking operations. The disclosure of environmental management policy is an integral part of sustainability reporting (Lock \& Seele 2015). Banks are increasingly engaged in implementation of environment management system as it leads to reduced resource consumption and costs optimisation (Sahoo \& Nayak 2007; Jizi 2014; Ihlen et al. 2014; Chaklader \& Gulati 2015). Jeucken (2001) stressed on the disclosure of both qualitative and quantitative data on environmental care practices undertaken by banks in their nonfinancial reporting.

In sustainability reporting literature, social conduct of the financial institutions is most commonly measured through the extent of disclosure of various sustainability indicators in nonfinancial reporting i.e. community development programs, health care programs and training and development programs (Frost et al. 2005; Raman 2006; Murthy 2008; Belal 2008; Adams et al. 2008; Kopnina 2017). Banks are increasingly reporting financial literacy and financial inclusion initiatives as part of their nonfinancial disclosure to communicate socially responsible business conduct to various stakeholders (Kamath 2007; Sarma \& Pais 2011). The disclosure of policies related to business ethics/values and human rights is an important tool to upturn transparency and sustainability performance of banking institutions (Jeucken 2001; Scholtens 2009). Islam et al. (2016) emphasised that implementation of anti-corruption and decent labour practices is essential to improve sustainability performance of financial institutions. Khan et al. (2009) noted that sustainability practices like environment management system, community development initiatives, business ethics, human rights and environmental policy are the basic content of global frameworks on sustainability such as GRI, UNGC principles etc.

\section{Prior researches on CSR reporting in India}

In one of the studies in the past century, Singh and Ahuja (1983) studied thirty three items of social disclosure in the annual reports of 40 public sector companies in India 
using content analysis. Porwal and Sharma (1991) conducted a study on public and private sector companies in India and concluded that private sector companies made lesser disclosure as compared to public sector companies. Raman (2006) analysed the extent and nature of social reporting of top 50 companies in India by studying how top management perceives CSR and CSR report. It was found the community involvement is a key component in the social reporting and more emphasis is placed on development of human resource. Chaudhri and Wang (2007) examined CSR disclosure of top 100 IT companies in India and found that CSR disclosure was considerably low and companies have not been able to leverage in terms of style of communicating CSR on to their websites. The quantity of CSR disclosure too is a question of concern. Murthy (2008) examined the annual reports of top 16 IT companies in India using content analysis and concluded that community development activities were the most common disclosure practices, then followed by environmental activities in the CSR reporting. Sustainability reporting in India is still in nascent stage and corporate sector is yet to fully recognize the relevance of CSR reporting for building a corporate reputation in a highly transparent market environment (Ghosh 2015). Ghosh (2017) also conducted empirical study on CSR reporting of select companies from 2009 to 2014 and analysed the CSR reporting practices for pre and CSR reporting mandate onset period. It was found that average CSR activities disclosure has increased in social reporting but still few companies publish a sustainability report separately. Jain \& Winner (2016) examined CSR/ sustainability report of 200 largest public and private sector companies in India and concluded that standard CSR/sustainability reporting is still low but shows positive signs of reforms. Kumar \& Kidwai (2018) conducted research on CSR disclosure of top 100 ET (2014) companies. It was found that only eight companies showed high transparency in their CSR disclosure and the companies focus heavily on social initiatives and human resource oriented activities in their disclosure. According to KPMG (2017) India has emerged as the top CSR reporting country along with Japan and Malaysia in Asia. CSR reporting by the companies has seen an improvement following the implementation of CSR rule of Indian Companies Act 2013. Education and health spending has been the major focus of companies CSR reporting. However, the quality of disclosure in CSR reporting is yet questionable and needs improvement.

Although CSR reporting by companies in India has witnessed an upsurge, the disclosure of sustainability report is in infant stage (Goel \& Misra 2017). Given the role of banking sector in promoting sustainable development, it is pertinent to examine the current status of sustainability reporting practices in Indian banking sector.

\section{Initiatives taken to promote corporate sustainability in India}

The following discussion lists out the steps taken by The Government of India (GOI) to address sustainability issues in corporate conduct in the recent past. With a view to review the CSR practices and to ensure responsible business conduct at par with the global frameworks on sustainability (for example GRI, CDP), the Ministry of Corporate Affairs Government of India established National Voluntary Guidelines (NVGs) based 
on social, environmental, and economic responsibilities of business in July 2011. Following this, The Securities Exchange Board of India (SEBI) in August 2012 made it mandatory for top 100 BSE and NSE listed companies to disclose their CSR initiatives and adherence to the NVGs framework through their business responsibility reports (SEBI 2012). In 2013, India took a lead and has become the first country in the world to legislate spending of profits on CSR activities. Section 135 of Indian Companies Act, 2013 mandates all companies operating in India with a minimum net worth of Rs 500 crore or turnover of Rs 1000 crore or the net profit of at least Rs 5 crore, to spend at least $2 \%$ of their profits of the last three proceeding years on CSR activities. Schedule VII of Indian Companies Act 2013 specifically provides the list of ten activities where a company can spend to deliver its CSR obligations. The companies have to constitute CSR committee comprising three or more Board of Directors, responsible for preparing the CSR policy and review the practices undertaken by the company as per their CSR policy. The Reserve Bank of India (RBI) is also working on formulating policy framework for green financing to align Indian banking sector with other nations already having such policies (RBI working on green finance framework 2017). Rajput et al. (2013) noted that banking industry in India is running far behind when it comes to adoption of sustainability issues. It is high time to takes some major steps to gradually adhere to the international principles, guidelines that provide environmental and social performance parameters apart from financial viability criteria in project financing. The RBI notification, dated 20th November 2007 (RBI 2007-2008/216) highlighted banks need to act with responsibility and contribute to sustainable development so that the adverse impact on the environment can be reduced. RBI also advised banks to formulate an appropriate and efficient action plan with the approval of their respective board for helping the cause of sustainable development in India.

\section{Overview of Indian banking sector}

The Indian banking system is broadly classified into five categories- public sector banks (PSBs), private sector banks, foreign banks, regional rural banks (RRBs) and co-operative banks enshrined in the second schedule of Reserve Bank of India Act, 1934. There are 21 PSBs, 21 private sector banks, 43 foreign banks, 56 RRBs, 1589 urban cooperative banks and 93,550 rural cooperative banks (RBI 2017). In FY 2017, total banking sector assets in India aggregate to US\$ 2.202 trillion and have increased at a CAGR of 8.83\% between FY 2013 to 2017. The PSBs and private sector banks in India account for more than $90 \%$ of the total banking assets (RBI 2017). The PSBs occupy most dominant position in commercial banking in India. In term of total banking system assets, PSBs account for more than 70\% (US\$ 1.52 trillion) of the total banking assets, thereby leaving comparatively smaller share for private sector banks and foreign banks (RBI 2017). Traditionally, the burden of social development has largely been shouldered by PSBs and they have been in the forefront of channelizing financial resources from remote areas as well as expanding the outreach of banking services in the remotest part of the country (Chaudhary \& Sharma 2011). Both PSBs and private sector banks have played a crucial role in meeting the resources required for a rapidly growing Indian economy and have been the main source of credit for various sectors of the economy (Kumar et al. 2016). 


\section{Purpose of the study}

The primary objective of this study is to examine sustainability reporting tendencies of public and private sector banks in India vis-a-vis the indicators provided in two major sustainability disclosure frameworks namely GRI G4 guidelines and NVGs. In addition the study attempts to answer the following research questions;

- To what extent do banks report broad area of sustainability in their nonfinancial report?

- What sustainability indicators do public and private sector banks in India report in line with the indicators provided in GRI G4 guidelines and NVGs?

- Has there been a difference in the sustainability disclosure of public and private sector banks in India?

\section{Methodology and data collection}

The sample of the study consists of the population of PSBs and private sector banks operating in India. The sustainability report, business responsibility report, corporate social responsibility report, annual report of the banks for the financial year 2015-16 \& 2016-17 were investigated and key indicators from these reports were analysed using the content analysis technique.

The banking sector (PSBs and private sector banks) has been chosen in the present study for the following reasons; the integration of sustainability in banking has become imperative for ensuring the sustainable growth in any country (Jeucken 2001; Achua 2008). Although many studies have been conducted on nonfinancial reporting in developed and developing economies across different sectors, there is dearth of studies related to sustainability disclosure tendencies of banks in developing economies (Khan et al. 2009; Jain et al. 2015). The disclosure practices of environmental and social performance by the Indian banking sector remains understudied (Kumar \& Prakash 2017). This study provides insights into the extent of sustainability reporting by the banks in India vis-a-vis prominent sustainability disclosure standards like GRI and NVGs. Further, the study contributes to sustainability reporting literature specifically in the Indian context and possibly accelerates the progress in sustainability reporting in banking sector.

\section{Content analysis}

Content analysis is used as a research technique to focus on actual content (Miles \& Huberman 1994). It is used to capture the data from reports or any other document and to quantify the presence or absence or extent of the required information (Gray et al. 1995; Kothari et al. 2009). Content analysis has been consistently used in prior social and environmental reporting researches (Hackston \& Milne 1996; Unerman 2000; Adams \& Frost 2008; Scholtens 2009; Haque \& Deegan 2010; Islam \& McPhail 2011; Pistoni et al. 2018; Landrum \& Ohsowski 2018). With respect to the research questions, broad sustainability disclosure indicators were identified and then investigated from various reports of the banks. These indicators are derived from available literature and prominent sustainability standards \& guidelines like GRI G4 guidelines, UNGC principles and NVGs. These standards have been used in previous researches as the basis for 
examining the extent of nonfinancial disclosure as discussed in the literature. The indicators are divided into three groups;

The first set is grouped as environmental indicators, which reflects how the banks take care of environmental issues. It includes environment policy, environmental management system, the disclosure of qualitative data about environmental care, and the disclosure of quantitative data about environment care (Jeucken, 2001; Scholtens 2009; Jizi 2014; Ihlen et al. 2014; Lock \& Seele 2015; Islam et al. 2016). The second set is grouped as the social development conduct of the bank, which reflects on the broad areas of banks socially responsible practices and involves community development programs, health care program, training \& education program, and financial literacy and access of financial services to deprived section of the society (Frost et al. 2005; Raman 2006; Belal 2008; Kamath 2007; Sarma \& Pais 2011; Kopnina 2017). The third set is grouped as the internal socio-environmental conduct of banks, which reflects the various policies of banks related to business ethics/values, anti-corruption, human rights and labour practices (Jeucken 2001; Scholtens 2009; Islam et al. 2016). Further, this study identifies sustainability disclosure by banks, who specifically embrace environmental and social indicators provided in prominent sustainability-related disclosure frameworks such as GRI G4 guidelines along with specific financial service sector indicators, and NVGs on social environmental and economic responsibilities of business. However, it must be noted that certain indicators of GRI G4 guidelines were not included as it seemed impractical keeping in mind the nature of banking operations. Each bank was given a score of either 1 (present) or 0 (absent) for each indicator on the basis of whether the practices are undertaken by the bank or not and subsequently whether the bank discloses the same.

\section{Hypotheses}

The third objective of the study was addressed by testing following hypotheses.

$\mathrm{H} 1$ : There is a significant variation in the disclosure of environmental consideration indicators between the PSBs and private sector banks in India.

$\mathrm{H} 2$ : There is a significant variation in the disclosure of social development indicators between the PSBs and private sector banks in India.

H3: There is a significant variation in the disclosure of internal socio-environment conduct indicators between the PSBs and private sector banks in India.

Environmental consideration practices, social development practices, and internal socio-environment conduct are the three crucial dimensions of sustainability reporting. The understanding of the extent of disclosure by PSBs and private sector banks regarding these indicators is important for the development of sustainability reporting in Indian banking sector.

\section{Analysis and findings}

As mentioned in the previous section, we identified broad areas of sustainability disclosure to investigate the extent to which banks report sustainability issues in their nonfinancial report. Table 1 shows the nonfinancial disclosure of banks in India with respect to three critical issues of sustainability. The total number of PSBs and private sector banks disclosing information was counted for each of the sustainability indicators provided in 
Table 1 Disclosure of broad sustainability issues by the banks in India (Figures in percentage, of number of PSBs $=21$, number of private sector banks = 21)

\begin{tabular}{lll}
\hline General area of disclosure & $\begin{array}{l}\text { Percentage of PSBs } \\
(N=21)\end{array}$ & $\begin{array}{l}\text { Percentage of PvtSBs } \\
(\mathrm{N}=21)\end{array}$ \\
\hline Environmental consideration indicators & 95.2 & 52.4 \\
Environment policy & 19 & 23.1 \\
Environmental management system & 38.1 & 28.6 \\
Disclosure of qualitative data about environmental care & 100 & 47.6 \\
Disclosure of quantitative data about environment care & & 100 \\
Social development indicators & 100 & 95.2 \\
Community development programs & 100 & 90.5 \\
Health care program & 95.2 & 100 \\
Training \& education program & 100 & \\
Financial literacy \& financial inclusion program & & 52.4 \\
Internal socio-environment conduct indicators & 95.2 & 66.7 \\
Policy for human rights & 95.2 & 66.7 \\
Policy for anti-corruption & 95.2 & 52.4 \\
\hline Policy for labour practices & 95.2 & \\
Policy for business ethics/values &
\end{tabular}

Table 1. It was found that both PSBs and private sector banks in India are actively engaged in addressing social dimension of sustainability as almost all banks disclosed information about community development program, financial literacy, and information about financial inclusion. However, the environmental consideration practices were limited to the statement of the policy towards environment protection. Among the PSBs 95.2\% of the total PSBs have established environment policy, but when it comes to the disclosure of quantitative data with respect to environmental care practices only $38.1 \%$ PSBs disclosed the concerned information. In case of private sector banks $52.4 \%$ have disclosed any kind of environment policy and when it comes to disclosure of quantitative data about environmental care practices, only $28.6 \%$ private sector banks have disclosed the same. Establishment of an environmental management system in the banks were quite low among both the PSBs and private sector banks. The performance of PSBs was far better than private sector banks in case of disclosure of internal socio-environment conduct indicators. All PSBs have disclosed policies related to human rights, anti-corruption, labour practices and business ethics/values except for one (Indian overseas bank). The policy related to human rights and business ethics/values is disclosed by $52.4 \%$ private sector banks, $66.7 \%$ private sector banks disclosed the policy related to anti corruption and labour practices. The reason for better performance of PSBs with regards to the disclosure of internal socio-environmental conduct and social development indicator was the higher adoption rate of NVGs by the PSBs as compared to the private sector banks.

The nonparametric Mann-Whitney $U$ test was performed in order to determine significant variation among the three categories of sustainability disclosure between PSBs and private sector banks in India. H1 and H3 are supported whereas, H2 is not supported. The results of Mann-Whitney $U$ test reveal that the disclosure of environmental consideration indicators by PSBs (Mean $=25.5)$ is significantly higher than private sector banks (Mean =17.5), $U=136.5, z=-2.178, p=.029$. The disclosure of internal socio-environmental conduct indicators by PSBs (Mean $=25.93$ ) is also significantly 
higher than private sector banks (Mean $=17.07), U=127.5, z=-3.043, p=.002)$. However, there is no significant variation in the disclosure of social development indicators between PSBs (Mean = 22.50) and private sector banks (Mean = 20.5), $U=199.5, z=-$ $1.039, p=.299$. The findings of the study show that both PSBs and private sector banks disclosed most of the social development indicators in their nonfinancial reporting whereas, the disclosure of environmental consideration indicators and the internal socio-environment indicator is better among PSBs as against private sector banks in India. The increased level of adherence to the NVGs and BRR disclosure by PSBs has lead to a higher level of sustainability disclosure.

The second research question was addressed by investigating the extent of disclosure of nonfinancial performance reporting by PSBs and private sector banks vis-à-vis the key indicators provided in NVGs and GRI standards. With business responsibility reporting being made mandatory in India, thirty-one out of forty-two PSBs and private sector banks publish BRR. This indicates the level of disclosure of practices undertaken by the banks in line with NVGs. Table 2 shows the extent of the adoption of NVGs by the PSBs and private sector banks in India. In the case of PSBs, twenty out of twenty-one PSBs adhere to the NVGs and report principle-wise performance of NVGs in their BRR. However, it was found that although most of the banks have established some kind of policies to address each of the nine core principles provided in NVGs. The quantitative data which could have expressed the range of practices undertaken for each principle has not been disclosed by the banks. Principle 7 of NVGs which states 'bank engaging in influencing public policy in responsible manner' has been least reported as $71.4 \%$ of the total PSBs have established some kind of policy with respect to principle 7 . Similarly disclosure of the link to access information about the policy with regard to each principle was not reported by large number of banks. It is interesting to note that although most PSBs (except for Indian overseas bank) have formulated the policy for each principle provided in NVGs, more than half of the PSBs have not carried out any evaluation of the working of the policies or independent audit by any internal or external agency.

The adherence to NVGs was quite low in case of private sector banks. Only eleven banks out of twenty-one private sector banks report NVGs in BRR. Principle 7 of NVGs was also the least reported principle with only $19 \%$ of total private sector banks reporting some kind of public policy of the bank. The detailed disclosure of each of the principles by the PSBs and private sector bank is shown in Table 2.

The GRI is the most widely used standard adopted by organisations for sustainability reporting. It was found the adoption of GRI standards is still very low in Indian banks. Out of forty-two PSBs and private sector banks, only six banks (one PSB and five private sector banks) have adopted GRI standards for sustainability reporting. SBI is the first and only public sector bank in India to publish a sustainability report as per GRI standards. Axis, HDFC, IndusInd, YES, and IDFC bank are the five private sector banks that publish sustainability report as per GRI G4 guidelines. Tables 3 and 4 shows the disclosure of specific indicators in nonfinancial reporting of PSBs and private sector banks in India vis-a-vis the key indicators provided in GRI G4 guidelines and GRI FSS indicator. Since GRI standards provide the most comprehensive framework available for sustainability reporting and call for quantitative disclosure of each indicator provided in the GRI G4 standards, it is evident from the Tables 3 and 4 below that there is 


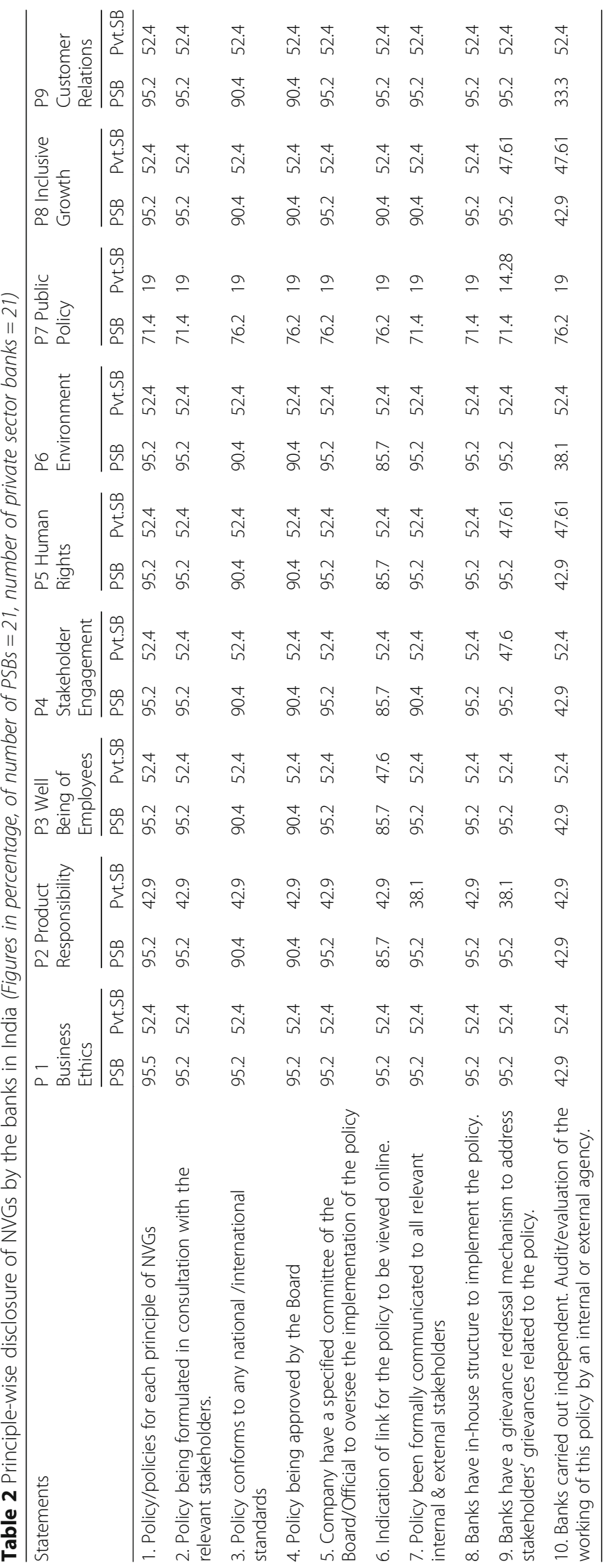


Table 3 Sustainability disclosure on specific indicators provided in GRI G4 standards by the banks

\begin{tabular}{|c|c|c|}
\hline GRI G4 Specific standard & No. of PSBs $(N=21)$ & No. of PvtSBs $(N=21)$ \\
\hline \multicolumn{3}{|l|}{ Category: Environment } \\
\hline Energy (E3-E6) & 1 & 5 \\
\hline Emissions (E15-E19) & 1 & 4 \\
\hline Effluent and waste (E23, E27) & 1 & 4 \\
\hline \multicolumn{3}{|l|}{ Category: Labour practice and decent work } \\
\hline Employment and benefits (L1-L3) & 20 & 11 \\
\hline Labour/Management relation(L4) & 8 & 5 \\
\hline Occupational health and safety (L6) & 4 & 5 \\
\hline Training \& education (L9-L11) & 12 & 11 \\
\hline Diversity and equal opportunity (L12) & 2 & 5 \\
\hline Labour practices and grievances mechanism (L16) & 15 & 9 \\
\hline \multicolumn{3}{|l|}{ Category: Human Right } \\
\hline Human right investment (HR1-HR2) & 0 & 5 \\
\hline Non-discrimination (HR3) & 13 & 9 \\
\hline Child labour (HR5) & 16 & 10 \\
\hline Forced or compulsory labour (HR6) & 12 & 10 \\
\hline Indigenous right (HR8) & 0 & 3 \\
\hline Human right grievance mechanism (HR12) & 10 & 10 \\
\hline \multicolumn{3}{|l|}{ Category: Society } \\
\hline Local communities program (SO1, SO2) & 20 & 15 \\
\hline Anti-corruption behaviour ( $\mathrm{SO} 3, \mathrm{SO} 4)$ & 14 & 11 \\
\hline
\end{tabular}

scant disclosure with regards to GRI G4 guidelines and GRI FSS indicator. It was found that most of the PSBs and private sector banks are inclined to disclose on social indicators whereas the information disclosed on environment category is relatively low. Axis, HDFC, IndusInd, YES, IDFC, and SBI are the only banks reporting on environment category of GRI G4 specific standard as shown in Table 3. The development of products and services like financial inclusion and women empowerment schemes are the most common sustainability practices undertaken by the banks in India. GRI FSS2, FSS 3, FSS 4, FSS 7, FSS 8, FSS 9, FSS 11 indicators was disclosed by only SBI (among PSBs) and none of the PSB made disclosure on FSS 6, FSS10, FSS 13.

\section{Conclusion and implications}

The sustainability disclosure by the organisations varies with region, level of socio-economic development, consumer preference, and regulatory environment in the country (UNEP FI, 2016). The banking sector in developing countries like India plays a crucial role in the economy to bolster economic growth with social development. The results of the study shows the social development indicators like (i.e. community development program, financial inclusion, training and education, and healthcare programs) are most common indicators of disclosure for both PSBs and private sector banks in their nonfinancial reporting. However, the disclosure of environmental indicators was relatively low as environmental care practices of most of the banks were confined to disclosing qualitative data about internal environmental care practices like paperless 
Table 4 Disclosure of GRI Financial Service Sector Supplement by Banks in India

\begin{tabular}{|c|c|c|c|}
\hline \multicolumn{2}{|c|}{ GRI Financial Service Sector Supplement } & \multirow{2}{*}{$\begin{array}{l}\text { Percentage of } \\
\text { PSBs }(N=21) \\
20\end{array}$} & \multirow{2}{*}{$\begin{array}{l}\text { Percentage of } \\
\text { PvtSBs }(\mathrm{N}=21) \\
20\end{array}$} \\
\hline$\overline{\text { FSS-1 }}$ & $\begin{array}{l}\text { Policies with specific environmental and social components } \\
\text { applied to business lines }\end{array}$ & & \\
\hline FSS-2 & $\begin{array}{l}\text { Procedures for assessing and screening environmental and } \\
\text { social risks in business lines }\end{array}$ & 1 & 6 \\
\hline FSS-3 & $\begin{array}{l}\text { Processes for monitoring clients' implementation of and } \\
\text { compliance with environmental and social requirements } \\
\text { included in agreements or transactions }\end{array}$ & 1 & 3 \\
\hline FSS-4 & $\begin{array}{l}\text { Processes for improving staff competency to implement } \\
\text { environmental and social policies and procedures } \\
\text { as applied to business lines }\end{array}$ & 1 & 2 \\
\hline FSS-5 & $\begin{array}{l}\text { Interactions with clients/ investees/business partners } \\
\text { regarding environmental and social risks and opportunities }\end{array}$ & 10 & 2 \\
\hline FSS-6 & $\begin{array}{l}\text { Percentage of the portfolio for business lines by specific } \\
\text { region, size (e.g. Micro/SME/Large) and by sector }\end{array}$ & 0 & 7 \\
\hline FSS-7 & $\begin{array}{l}\text { Monetary value of products and services designed to deliver } \\
\text { A specific social benefit for each business line broken down } \\
\text { by purpose }\end{array}$ & 1 & 6 \\
\hline FSS-8 & $\begin{array}{l}\text { Monetary value of products and services designed to deliver } \\
\text { a specific environmental benefit for each business line broken } \\
\text { down by purpose }\end{array}$ & 1 & 6 \\
\hline FSS-9 & $\begin{array}{l}\text { Coverage and frequency of audits to assess implementation } \\
\text { of environmental and social policies and risk assessment } \\
\text { procedures }\end{array}$ & 1 & 2 \\
\hline FSS-10 & $\begin{array}{l}\text { Percentage and number of companies held in the institution's } \\
\text { Portfolio with which the reporting organization has interacted } \\
\text { on environmental or social issues }\end{array}$ & 0 & 6 \\
\hline FSS-11 & $\begin{array}{l}\text { Percentage of assets subject to positive and negative } \\
\text { Environmental or social screening }\end{array}$ & 1 & 6 \\
\hline FSS-12 & $\begin{array}{l}\text { Voting policies applied to environmental or social issues for } \\
\text { shares over which the reporting organization holds the right } \\
\text { to vote shares or advises on voting }\end{array}$ & 0 & 2 \\
\hline FSS-13 & $\begin{array}{l}\text { Access points in low-populated or economically disadvantaged } \\
\text { areas by type }\end{array}$ & 0 & 6 \\
\hline FSS-14 & $\begin{array}{l}\text { Initiatives to improve access to financial services for } \\
\text { disadvantaged people }\end{array}$ & 21 & 21 \\
\hline FSS-15 & $\begin{array}{l}\text { Policies for fair design and sale of financial products and } \\
\text { services }\end{array}$ & 7 & 6 \\
\hline FSS-16 & Initiatives to enhance financial literacy by type of beneficiary & 21 & 21 \\
\hline
\end{tabular}

banking, installation of solar panel etc. It was found that sustainability issues which are of the highest priorities for the banks are directly related to their business operations like financial inclusion, financial literacy, energy efficiency etc. The disclosure of the environmental care practices and internal socio-environment conduct policies by the private sector banks was considerably low as compared to the PSBs. The increased adoption of NVGs and disclosure of BRR contributed to higher disclosure of sustainability indicators by PSBs as against private sector banks in India. Overall it was also found that sustainability reporting by banks in India is still in nascent stage and leaves more to be desired; only six banks (one PSB and five private sector banks) publish standardised sustainability report.

The adoption of international sustainability code of conduct like GRI standards, UNEP FI, UNGC principles, and Equator principles is very low. IDFC bank (private 
sector bank) is the only bank from India to adopt Equator principles and only YES bank (private sector bank) is the signatory to UNEP FI. Only one public sector bank (SBI) and three private sector banks (Axis, IDFC, and YES bank) report UNGC principles. The GRI standards for sustainability reporting are adopted by only six banks in India out of forty-two PSBs and private sector banks in India. These six banks have emerged as the role model for the other banks to lead the path towards adopting best sustainable reporting practices. With the rising trend of incorporating sustainability in banking globally, it has become imperative for the banking industry in India to integrate sustainability reporting into overall business strategy and graduate to the next level of nonfinancial reporting. This can be implemented by adopting various global sustainability code of conduct like GRI, UNGC principles EPs, UNEP FI etc.

The present study provides valuable insights into sustainable reporting practices of PSBs and private sector banks operating in India. This study also adds to the body of knowledge useful for banks and all the stakeholders in understanding more about the limitations that Indian banking industry has in implementing standard sustainable reporting. This provides a unique opportunity to improve sustainability disclosure at par with global standards. For instance, environment disclosure indicators are clearly under-reported by most of the banks except for GRI adopting banks and the non-disclosure of NVGs by almost half of the private sector banks. On the policy level, both PSBs and private sector banks in India need to further standardize their nonfinancial reporting and move beyond from BRR disclosure as a mere compliance of regulatory requirement in India to standardised sustainability reporting.

\section{Limitations and future research}

Despite having explored significant practical implications in the field of nonfinancial disclosure by the banks in India, this study has few limitations also. In the present study the non financial performance disclosure by the banks for FY 2015 to 2017 has been analysed but the finding might change over the period of time. Therefore, longitudinal study may provide more insights into the trends in sustainable reporting practices of Indian banking sector. The Indian banking sector in addition to PSBs, private sector banks also include regional rural banks (RRBs) and foreign banks, which although forms small representation were not considered in the study. Since the sustainability reporting by the banks in India is very low, this study has taken into consideration the broad indicators of various dimensions of sustainability reporting. The study only reflects the nature and extent of the sustainability disclosure by commercial banks operating in India. The economic indicators of sustainability were also neglected in the present study. These issues could be addressed in future researches.

Acknowledgments

Not Applicable.

Funding

There is no funding applicable for this project.

Availability of data and materials

Please contact author for data requests.

Authors' contributions

Both authors contributed equally and approved the final manuscript. 
Competing interests

We declare that we do not have any competing interests.

\section{Publisher's Note}

Springer Nature remains neutral with regard to jurisdictional claims in published maps and institutional affiliations.

Received: 1 June 2018 Accepted: 10 December 2018

Published online: 10 January 2019

\section{References}

Achua JK (2008) Corporate social responsibility in Nigerian banking system. Soc Bus Rev 3(1):57-71

Adams CA, Frost GR (2008) Integrating sustainability reporting into management practices. Accounting Forum, Elsevier 32(4): 288-302

Ali W, Frynas JG, Mahmood Z (2017) Determinants of corporate social responsibility disclosure in developed and developing countries: a literature review. Corp Soc Responsib Environ Manag 24(4):273-294

Babiak K, Trendafilova S (2011) CSR and environmental responsibility: motives and pressures to adopt green management practices. Corp Soc Responsib Environ Manag 18(1):11-24

Belal AR (2008) Corporate social responsibility reporting in developing countries: the case of Bangladesh. Routledge, London

Boiral O, Henri JF (2017) Is sustainability performance comparable? A study of GRI reports of mining organizations. Bus Soc 56(2):283-317

Chaklader B, Gulati PA (2015) A study of corporate environmental disclosure practices of companies doing business in India. Glob Bus Rev 16(2):321-335

Chaudhary K, Sharma M (2011) Performance of Indian public sector banks and private sector banks: a comparative study. International Journal of Innovation Management and Technology 2(3):249-256

Chaudhri V, Wang J (2007) Communicating corporate social responsibility on the internet: a case study of the top 100 IT companies in India. Manag Commun Q 21:232-247

Dyllick T, Hockerts K (2002) Beyond the business case for corporate sustainability. Bus Strateg Environ 11(2):130-141

Frost G, Jones S, Loftus J, Laan S (2005) A survey of sustainability reporting practices of Australian reporting entities. Aust Account Rev 15(35):89-96

Ghosh S (2015) Is corporate social responsibility in India still in a confused state? A study of the participation of the private sector companies of India in corporate social responsibility activities. Glob Bus Rev 16(1):151-181

Ghosh S (2017) Reporting of CSR activities in India: are we still at a nascent stage even after the legal mandate? In: Corporate Social Responsibility in India. Springer, Cham

Goel P, Misra R (2017) Sustainability reporting in India: exploring sectoral differences and linkages with financial performance. Vision 21(2):214-224

Gray R, Kouhy R, Lavers S (1995) Corporate social and environmental reporting: a review of the literature and longitudinal study of UK disclosure. Account Audit Account J 8(2):47-77

Gupta SK, Mohanty SC (2014) Convergence of cost accounting standards (CASs) and national voluntary guidelines (NVGs). The MA Journal 49(11):90-92

Hackston D, Milne MJ (1996) Some determinants of social and environmental disclosures in New Zealand companies. Account Audit Account J 9(1):77-108

Haque S, Deegan C (2010) Corporate climate change-related governance practices and related disclosures: evidence from Australia. Aust Account Rev 20(4):317-333

Healy PM, Hutton A, Palepu KG (1999) Stock performance and intermediation changes surrounding sustained increases in disclosure. Contemp Account Res 16(3):485-520

IFC (2007) Banking on sustainability: Financing environmental and social opportunities in emerging markets http:// documents.worldbank.org/curated/en/434571468339551160/Banking-on-sustainability-financing-environmental-andsocial-opportunities-in-emerging-markets. Accessed 09 Nov 2018.

Ihlen $\varnothing$, Roper J (2014) Corporate reports on sustainability and sustainable development: we have arrived. Sustain Dev 22(1): $42-51$

Isaksson R, Steimle U (2009) What does GRI-reporting tell us about corporate sustainability? The TQM Journal 21(2):168-181

Islam MA, Jain A, Thomson D (2016) Does the global reporting initiative influence sustainability disclosures in Asia-Pacific banks? Aust J Environ Manag 23(3):298-313

Islam MA, McPhail K (2011) Regulating for corporate human rights abuses: the emergence of corporate reporting on the ILO's human rights standards within the global garment manufacturing and retail industry. Crit Perspect Account 22(8): 790-810

Jain A, Keneley M, Thomson D (2015) Voluntary CSR disclosure works! Evidence from Asia Pacific banks. Social Responsibility Journal 11(1):2-18

Jain R, Winner LH (2016) CSR and sustainability reporting practices of top companies in India. Corp Commun Int J 21(1):36-55

Jenkins H, Yakovleva N (2006) Corporate social responsibility in the mining industry: exploring trends in social and environmental disclosure. J Clean Prod 14(3-4):271-284

Jeucken M (2001) Sustainable finance and banking, the finance sector and the future of the planet. Earthscan, London. https://doi.org/10.1016/S1462-9011(03)00009-1.

Jeucken M H A, Bouma J J (1999) The changing environment of banks. Greener management international, Autumn 1999 (27): $21-35$.

Jizi MI, Salama A, Dixon R, Stratling R (2014) Corporate governance and corporate social responsibility disclosure: evidence from the US banking sector. J Bus Ethics 125(4):601-615

Johnsen DB (2003) Socially responsible investing: a critical appraisal. J Bus Ethics 43:219-222. https://doi.org/10.1023/A: 1022998232503. 
Kamath R (2007) Financial inclusion Vis-à-Vis social banking. Econ Polit Wkly 42(15):1334-1335.

Khan MHUZ, Halabi A, Samy M (2009) CSR reporting practice: a study of selected banking companies in Bangladesh. Social Responsibility Journal 5(3):344-357

Kopnina H (2017) Sustainability: new strategic thinking for business. Environ Dev Sustain 19(1):27-43

Kothari SP, Li X, Short JE (2009) The effect of disclosures by management, analysts, and business press on cost of capital, return volatility, and analyst forecasts: a study using content analysis. Account Rev 84(5):1639-1670

KPMG (2015) Currents of change: KPMG survey of corporate responsibility reporting 2015. https:/assets.kpmg.com/content/dam/ kpmg/pdf/2016/02/kpmg-international-survey-of-corporate-responsibility-reporting-2015.pdf. Accessed 28 December 2017.

KPMG(2017) India CSR repeorting surveey 2017. https://assets.kpmg.com/content/dam/kpmg/in/pdf/2018/02/CSR-SurveyReport.pdf. Accessed 23 Dec 2017

Krosinsky C, Robins N (2008) Sustainable investing: the art of long term performance. Earthscan, London

Kumar K, Prakash A (2017) A new model for Indian banking industry towards environmentally sustainable development practices. Al Barkaat Journal of Finance and Management 9(2):146-160

Kumar M, Charles V, Mishra CS (2016) Evaluating the performance of Indian banking sector using DEA during post-reform and global financial crisis. J Bus Econ Manag 17(1):156-172

Kumar S, Kidwai A (2018) CSR disclosures and transparency among top Indian companies. International Journal of Indian Culture and Business Management 16(1):57-70

Landrum NE, Ohsowski B (2018) Identifying worldview on corporate sustainability: a content analysis of corporate sustainability report. Bus Strateg Environ 27(1):128-151

Lock I, Seele P (2015) Analyzing sector-specific CSR reporting: social and environmental disclosure to investors in the chemicals and banking and insurance industry. Corp Soc Responsib Environ Manag 22(2):113-128

Marrewijk M (2003) Concepts and definitions of CSR and corporate sustainability: between agency and communion. J Bus Ethics 44:95-105

Miles MB, Huberman AM (1994) Qualitative data analysis: an expanded source book. Sage, Newbury Park, CA

Milne MJ, Gray R (2007) Future prospects for corporate sustainability reporting. In: Unerman J, Bebington J, O'Dwyer B (eds) Sustainability accounting and accountability. Routledge, New York

Mitra N, Schmidpeter R (2017) The why, what and how of the CSR mandate: the India story. Corporate social responsibility in India. Springer, Cham

Murthy V (2008) Corporate social disclosure practices of top software firms in India. Glob Bus Rev 9(2):173-188

Pistoni A, Songini L, Bavagnoli F (2018) Integrated reporting quality: an empirical analysis. Corp Soc Responsib Environ Manag 25(4):489-507

Porwal LS, Sharma N (1991) Social responsibility disclosure by Indian companies. The Chartered Accountant 39(8):630-635

RBI (2017) Report on trend and progress of banking in India 2016-17. https://rbidocs.rbi.org.in/rdocs/Publications/PDFs/ ORTP20161778B7539711F14E088A31D52351BF6440.PDF. Accessed 15 July 2017.

Rajput N, Kaura R, Khanna A (2013) Indian banking sector towards a sustainable growth: a paradigm shift. International Journal of Academic Research in Business and Social Sciences 3(1):290-304

Raman SR (2006) Corporate social reporting in India: a view from the top. Glob Bus Rev 7(2):313-324

Roca LC, Searcy C (2012) An analysis of indicators disclosed in corporate sustainability reports. J Clean Prod 20(1):103-118

Sahoo P, Nayak BP (2007) Green banking in India. The Indian Economic Journal 55(3):82-98

Salzmann O, lonescu-Somers A, Steger U (2005) The business case for sustainability: literature review and research options. Eur Manag J 23(1):27-36

Sarma M, Pais J (2011) Financial inclusion and development. J Int Dev 23(5):613-628

Scholtens B (2006) Finance as a driver of corporate social responsibility. J Bus Ethics 68(1):19-33

Scholtens B (2009) Corporate social responsibility in the international banking industry. J Bus Ethics 86(2):159-175

SEBI (2012) Business responsibility reports. www.sebi.gov.in/cms/sebi_data/attachdocs/1344915990072.pdf. Accessed 18 Aug 2017.

Sethi SP, Rovenpor JL, Demir M (2017) Enhancing the quality of reporting in corporate social responsibility guidance document: The role of ISO 26000, GRI and CSR-Sustainability monitor. Bus Soc Rev 122(2):139-163

Singh DR, Ahuja JM (1983) Corporate social reporting in India. Int J Account 18(2):151-169

Unerman J (2000) Methodological issues-reflections on quantification in corporate social reporting content analysis. Account Audit Account J 13(5):667-681

van Gelder J W (2006) The dos and don'ts of sustainable banking https://www.banktrack.org/download/the_dos_and_donts_ of sustainable banking/061129 the dos_and_donts_of sustainable banking_bt manual.pdf. Accessed 10 Mar 2018.

Weber O, Diaz M, Schwegler R (2014) Corporate social responsibility of the financial sector-strengths, weaknesses and the impact on sustainable development. Sustain Dev 22(5):321-335

Weber O, Fenchel M, Scholz RW (2008) Empirical analysis of the integration of environmental risks into the credit risk management process of European banks. Bus Strateg Environ 17(3):149-159

Willis CA (2003) The role of the global reporting initiative's sustainability reporting guidelines in the social screening of investments. J Bus Ethics 43(3):233-237 